\title{
Excursions
}

Volume 4, Issue 1 (June 2013) Science/Fiction

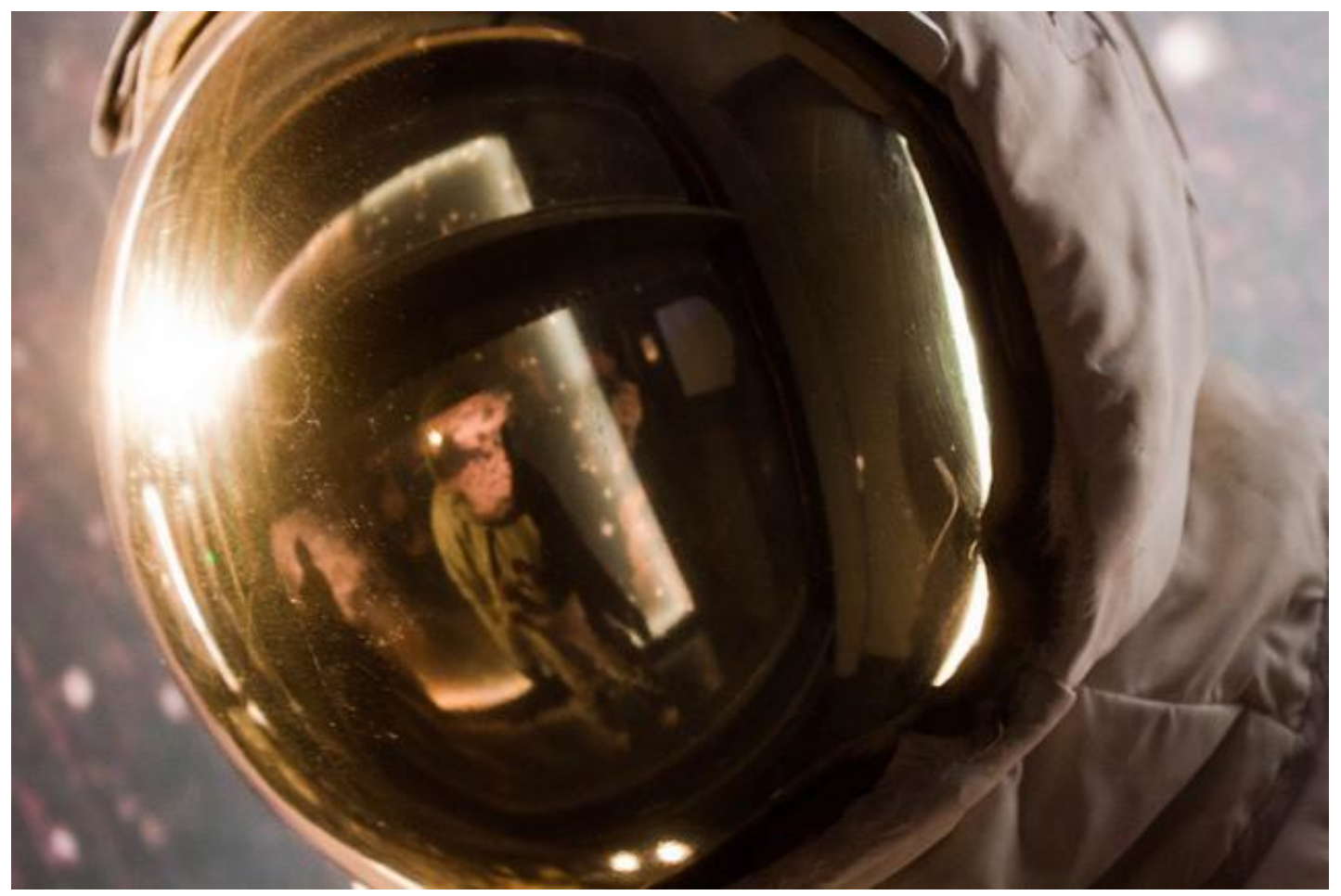

Image credit: Tangi Bertin (www.flickr.com/photos/tangi bertin/) CC by 2.0

Rónán L. MacDubhghaill, "The Myth of the Jedi: Memory and Deception in the Star Wars Saga",

Excursions, vol. 4, no. 1 (2013)

www.excursions-journal.org.uk/index.php/excursions/article/view/89 


\section{The Myth of the Jedi: Memory and Deception in the Star Wars Saga ${ }^{1}$}

The importance of science fiction in contemporary cultural studies can hardly be underestimated, no more than it can be denied. Many narratives that have emerged from this genre have become fully integrated within the contemporary canon of popular understanding, mythology and reference. Amongst these narratives, perhaps no story is more fully integrated with contemporary culture than the original Star Wars saga. This is evidenced not merely by box office takings, nor prizes and accolades, but in the wealth of images it inspires in the audience's collective imagination, the tribes of fans, and the many popular manifestations, such as the recent 'Vote Darkside' campaign in the 2012 French presidential elections (United States of Paris, 2012). More current in the contemporary social imagination than the Ulster cycle, the Norse sagas, or the epics of ancient Greece, the Star Wars saga shares many of their qualities. The focus on the heroic characteristics of individuals, for example, against the backdrop of a great conflict between forces of good and evil, in which the righteous and the virtuous prevail, is the standard narrative of many epic cultures. Indeed, the film reproduces classic notions of virtue which philosopher Alistair MacIntyre (2007) identifies as 
first articulated in these classic works. Perhaps it is this, the resurfacing of an 'essentialised' representation (the imaginaire) of the ancient in contemporary clothing that has ensured the saga's enduring relevance. Yet, as with the classical sagas, one must be sensitive to problematic aspects within their narratives; to the version of morality they promote, and the ways in which they do so. This main focus in this essay will be just one such problem: the (mis)use of memory within the narrative of the original Star Wars saga, and deception as it relates to the myth of the Jedi.

\section{A False Hope?}

In the original Star Wars movies, Episode IV: A New Hope (1977), Episode V: The Empire Strikes Back (1980) and Episode VI: The Return of the Jedi (1983), the order of Jedi Knights are portrayed as being, or rather as having been, a force for 'good'. Along with the Rebel Alliance they represent-or aspire to represent-an alternative to the apparently 'evil' galactic empire ruled by Darth Vader and the character known as 'The Emperor'. As the original Jedi Knight, Obi-Wan Kenobi, says in Episode IV: A New Hope: "for over a thousand generations the Jedi knights were the guardians of peace and justice in the Old Republic. Before the dark times. Before the Empire." It is noteworthy that this description is then immediately followed by Obi-Wan's first lie to Luke Skywalker, upon being asked how his father died:

A young Jedi named Darth Vader, who was a pupil of mine-until he turned to evil-helped the Empire hunt down and destroy the Jedi Knights. He betrayed and murdered your father. Now the Jedi are all but extinct. Vader was seduced by the dark side of the force.

With this, we see the beginning of Luke Skywalker's path toward becoming a Jedi Knight, or believing that he is one. Throughout the film, he is portrayed as an idealistic crusader who sacrifices his personal life, his feelings, and ultimately his hand, in the fight for the supremacy of 'good' over 'evil'. However, the problematic nature of such basic categorisations becomes immediately obvious if we think about contemporary political discourses, and the way in which, for just one example, human rights are often used as little more than an excuse for military interventions with other objectives. As Gregg 
Muttitt (2011) amply demonstrates in his book Fuel on the Fire, in the case of the occupation of Iraq, the discourse of progress and of human rights was used to justify not only the occupation, but also the imposition of multinational corporations upon what had been a hitherto functional domestic oil industry. The subtleties of what could be described as the postmodern 'democratic' colonialism that was the coalition occupation of Iraq do not easily lend themselves to being understood in black and white terms, mixing private interest with the smokescreen of a humanitarian intervention. As Muttitt shows, this discourse was used in order to open up oil production, in order to facilitate its exploitation, and increase global oil supply. This insight, however, can hardly be called new from a theoretical perspective. Writing in 1886, Friedrich Nietzsche (2002) demonstrated that the subjective juxtaposition of 'good versus evil' most often serves to further the aims of one or another power regime, naturalizing the morality of the master-slave social relationship. There is, as he said, "No such thing as moral phenomena, but only a moral interpretation of phenomena" (p.108).

It is my contention that this is precisely the kind of relationship and juxtaposition that we can see emerging in the original Star Wars saga. This becomes increasingly evident throughout the series of films, as we learn more about the imaginary origins of the Jedi Knights. As the saga progresses, the character of Luke Skywalker, who was at the outset so naive, becomes increasingly assertive, taking justice into his own hands in the extra-juridical killing of those that get in his way in his quest to overthrow The Emperor and his 'evil' regime, regardless of whether they are allied with The Emperor, or neutral elements who get in the way of his often private interests, as the massacre of Jabba the Hutt and his colleagues demonstrates. Whatever the cost, Luke Skywalker seems determined to reinstate the 'Old Republic', a regime we know almost nothing about from the original Star Wars saga. This is not to say that the Empire is the legitimate or ideal form of government for the galaxy 'far, far away', but at no point does the Rebel Alliance outline the future form of government which they intend to bring to the galaxy, except to say that they intend to resurrect the 'Old Republic'. As the works of Michel Foucault $(1980 ; 1984 ; 1984 a)$ have amply shown, there is no society or political order free of power relations, from its own abuses and oppressions, even if the forms of power relations present are occasionally, or even often, for 
some or for many, conducive to the realisation of certain human capacities. As Foucault has said, "power relations are rooted deep in the social nexus, [...] to live in a society is to live in such a way that action upon other actions is possible-and in fact ongoing. A society without power relations can only be an abstraction" (1982, pp.222-23). Hence, we should question the character of the Rebel Alliance, rather than simply accepting its beneficent self-presentation. A major weakness in the Rebel Alliance's plans is that they in no way make explicit the mechanisms by which they intend to govern the galaxy after disposing of the Empire, or deal with its potential inequity or abuse of power.

To problematise this characterisation of the Rebel Alliance and the Galactic Empire in the terms of 'good' and 'evil', we may, for example, examine the manner in which the Rebel Alliance manages its command structure. From the beginning of the saga, where Princess Leia has inherited a position of command, we can observe this. Who has sanctioned her? To what 'republican' mechanism of oversight is she responsible? Is the monarchy of her home planet Alderaan a constitutional one? Of course, none of these questions are ever posed, let alone answered. Perhaps the clearest exposition of this comes in Episode VI: Return of the Jedi, when Han Solo and Lando Calrissian are appointed generals in preparation for the attack on the rebuilt Death Star. For all their apparent fighting prowess, however, their main qualification for the post of general of the Rebel Alliance forces seems to be their relation with Princess Leia, and this decision appears to be made with little to no equitable consultation, the other members of the Alliance obliged to kowtow to the will of the Princess. At best, this could suggest an affectionate reward for services carried out, or at worse, a slide towards autocracy and arbitrary decision making, as countless other soldiers in the service of the Rebel Alliance are overlooked as mere cannon fodder throughout the saga. Making reference again to the theory of Foucault (1997), this suggests something to us about the nature of the biopolitical settlement present in the Rebel Alliance's power structure, whereby proximity to the main figures of importance may result in a great many benefits.

If we consider the still ongoing uprisings taking place across North Africa and the Middle East, we could quickly conclude that deposing of one dictator, however terrible, leads neither immediately nor even necessarily to the realisation of freedom and democracy, which are expressed as being 
desirable and the purpose of the uprisings. This is not to argue for dictatorship, but it is certainly true that simply removing one government, especially with no clear programme for its replacement, is more likely than not to leave a vacuum of power into which any arbitrary force may step. A brief consideration of some historical examples also brings light to this subject; examining Weimar Germany, late-Tsarist Russia and Imperial China at the end of the Manchu dynasty, we could conclude that it was just such a weakness and a vacuum of power that allowed Hitler, Stalin and Mao to take power. What if, in the case of the Star Wars saga, after deposing Darth Vader and The Emperor, the Alliance was too frail to prevent a third party taking power? All of this, of course, assumes that the desirable biopolitical settlement is the representative, or apparently 'republican' arrangement presented in the Star Wars saga. In this way, we can see Star Wars crystalising many of the problematic qualities of power relations present in our own societies. Here, we could view the narrative as both a product and a cause of this bourgeois democratic 'myth of governance', whereby the representations of this myth simultaneously re-implicate us in it, and naturalise it.

This is a topic that merits our attention because of the ways in which it demonstrates the fault lines of ideology in our societies, allowing us to see the myths and discourses, which, to paraphrase Foucault (1980; 1997), encourage us to resubmit ourselves to the dominant power/knowledge discourse. This is a question that has been given significant attention with relation to film and popular culture, in particular by Slavoj Žižek(2006). Not only, then, do the mythologies of the Star Wars saga, and in particular those of the Jedi, reflect and represent the currents of morality, power and ideology in our societies, but they have been vigorously appropriated within the canon of popular culture, to the extent that this saga has become a cultural force in and of itself. Considering the profound interrelationship between cultural, social, and political phenomena, this cannot be dismissed as merely a whimsical analysis, but one which may give us insight into the subjectivity with which the language and practice of morality exists in contemporary culture, society and politics. Indeed, as 'Jedi' was recently added to the official UK census as an option for people to choose in their religious declarations, and given its own census code (Wikipedia, 2012), this analysis could hardly be more timely. 


\section{The Memory of the Jedi Knights}

In the Star Wars saga, we repeatedly encounter references to the Jedi Knights. However, with the exception of Obi-Wan Kenobi, the character known only as 'Yoda', and Luke Skywalker (who graduates to full 'Jedi-hood' late in the saga, in Episode VI: The Return of the Jedi), the Jedi Knights are notably absent. What is more evident, however, is the presence of what we could term the imaginaires of cultural memory in the Star Wars universe.

The term imaginaire was used by the French anthropologist and philosopher Gilbert Durand (1993; 1994) to describe the currents of imagination and pools of representations (such as books, stories, films) that run through the social body, and which have the structure of anthropological trajectories, influencing action, perception, choice and decision-making processes on an individual and collective level. These imaginaires both enrich and provide us with frames of understanding for "notre bassin sémantique" (literally "our semantic pool") (Durand, 1993, p.37). These imaginaires, and the imaginaire of the Jedi in particular for the world of the original Star Wars saga, have great emotional purchase in the societies in which they are based. As I have argued elsewhere, one of the means by which we can understand salient social imaginaires is through an analysis of representations and expressions of collective or cultural memory (MacDubhghaill, 2012).

Indeed, social imaginaires have been described by Michel Maffesoli (1985, p.107) as "une nouvelle façon de comprendre la mémoire collective" ("a new way to understand collective memory"), and for the purposes of the Jedi, and the narrative of memory surrounding them, this is a very useful analytical tool. Throughout the original Star Wars saga, as I have pointed out, the Jedi, as represented by Luke Skywalker, are effectively granted carte blanche in terms of their actions in the name of the Rebel Alliance, rendering them a super-juridical force arbitrarily appointed to bring about a violent objective. What is most striking about the Jedi is how little we actually know about them. There is, indeed, an apparent dearth of knowledge in the original Star Wars saga relating to the order of Jedi Knights, pointing to the fact that this imaginaire is, in the world of Star Wars, so deeply rooted in the collective memory of the characters that populate this world that it needs little to no explanation. 
At this point, I should stress that this analysis is concerned with Episodes IV, $V$ and $V I$ only, and not episodes I, II or III, nor the 'Clone wars' series or any other spinoffs from the original saga, which could in themselves be read as an attempt to legitimate the Jedi, the Rebel Alliance and the Republic, a posteriori. This is not so much a reflection of the greater cinematic qualities of the films, nor their superiority of style or aesthetic appeal, but it is rather a reflection of the fact that the original saga remains the Star Wars that people remember; it has the greatest emotional purchase, the strongest foothold in our collective imaginaires. Studying collective imaginaires is a way to examine fictional narratives as having a subjective importance that is often equal to, if not greater than, many of the 'real' narratives that occupy the stage of contemporary social and cultural discourses. In this sense, as Maffesoli (2012) has said, "le réal et les imaginaires sociaux jouer un rôle dans la vie quotidienne d'une importance égale, sinon supérieure, à celle des sèches et abstraite 'principe de réalité'qualitatif" ("the 'real' [here meant in the Lacanian sense of the real] and social imaginaires play a role in everyday life of an importance equal to, if not greater than, the dry and abstract qualitative 'principles of reality"'). Thus, we can consider the Star Wars saga both as text, as a fictional narrative and cultural product, but also as a wider universe of meaning that has become coextensive with large spaces in contemporary cultural discourse and understanding. For example, in the very way that the works of Shakespeare, Proust or Goethe have enriched and continue to inform the languages which we speak, and the way we understand them and each other, Star Wars, for better or for worse, has likewise become part of the canon of contemporary culture. After all, which of the following expressions is more current, more meaningful; "Cry 'Havoc', and let slip the dogs of war," or "May the force be with you"? In this way, these imaginaires, these assumed bases of everyday culture, are indispensable tools through which we understand ourselves and the world we live in, and how we take meaning from it. They become part of the knowledge that we use to understand the culture we inhabit.

An analysis of the narrative of memory present in the universe of the Star Wars saga is also useful and insightful, both theoretically, and also in considering Star Wars as a reflection of contemporary culture, in so far as many of the imaginaires are coextensive. Any discussion of memory, after all, 
implies the all-too-human ability to forget. Here, the capacity to forget plays a role which is seemingly symmetric to that of remembering; it is by its very absence that it is felt, and that it shapes our imaginaires. We relate to the past not as historians working in an empirical sense, but within the cadres which Maurice Halbwachs (1950) identified as informing and directing the way in which we remember, as individuals, societies, and cultures. Here, the forgotten acts in ways similar to the complex strategies and networks which Foucault (1980) described as directing power relations, both constraining and enabling action, facilitating the acceptance of certain discourses of knowledge (for the purposes of this essay, for example, the acceptance of narratives of memory). In this way, power is not necessarily concentrated in any political, economic or institutional structure, but rather in the social nexus itself (Foucault, 1984; 1984a). The currents of power relations in society contribute through what Foucault (1984a) termed "epistemological policing," which determines what become the accepted discourses of knowledge, the social truths. As Foucault has written, one might speak the truth in the "wild exteriority" but one is only ever "in the true" by obeying the rules of discursive "policing". For the purposes of analysing memory, then, this becomes useful in understanding not only what is remembered, but importantly what is not, and in the case of the Jedi, which memories are imposed.

This process goes hand in hand with the contours or power in society. It is by obeying what Foucault called the "epistimes" of a discourse that one may make what becomes a "true statement" (Simons, 2006)-for us, a 'true' memory. On this, Maffesoli (2006, p.34) has written that "Dans une dialectique sans fin, durant la modernité, le savoir et le pouvoir vont se conforter mutelement" ("In an ongoing dialectic, throughout modernity, knowledge and power have mutually reinforced one another"). For the purposes of our discussion on narratives of memory this is important, since it is via the process of discursive formation that certain instances and imaginaires (such as those of the Jedi in the case of Star Wars) become accepted and included within the narrative of memory, whilst other details fade into the background, are forgotten. Hence, the accepted narrative of memory becomes accepted as 'knowledge', and nobody questions the Jedi, with the sole exception of Jabba the Hutt. 
We can readily see the importance of the forgotten within the imaginaires we find in contemporary everyday life. In the world of the Star Wars saga, for example, it means the wealth of detail which forms the implicit, unquestioned base of knowledge-the narrative of memory-upon which the characters perceive the roles of each other and of themselves. That is to say that there are narratives of memory by which we relate to the past, which are formed and accepted in concert with the power relations in society, which amount to social 'truths' or discourses of knowledge in the Foucauldian sense as outlined above. The term narration, of course, implies selection; we cannot remember everything-behind each narrative of memory, behind each imaginaire there is the forgotten. This version of memory as narrative draws on the work carried out by prominent researchers in the field of memory studies, such as Jens Brockmeier (2002), and on my own previous research (MacDubhghaill 2012; 2013).

Biographical memory-although an idea which has been salient from ancient times through to modernity-is, according to Brockmeier, an impossibility. Since remembering every detail is impossible, we are necessarily bound to remember in the form of narrative (Brockmeier, 2000). In the case of Star Wars, we may see this in the way the Rebel Alliance accept Luke Skywalkwer's authority, thanks to the legacy and the imaginaire that the Jedi have in the universe of the Star Wars saga. We could understand this, perhaps, as being analogous for the kind of authority the Knights Templar once had in Medieval Europe-a self-appointed 'holy' order of warriors on a mystic quest.

The impossibility of biographic memory and its narrative aspect both suggest formal equality of the processes of remembering and forgetting. According to neuroscientific research, one of the main functions of human memory is to select that information which is deemed worth remembering, and to discard the rest (Quian Quiroga, 2011). Of course, the criteria by which memories are kept or discarded varies according to who is doing the remembering and the forgetting; individuals, tribal groupings, whole cultures or societies. That these criteria may seem arbitrary or subjective does little to prevent them from being potent markers of identity. The fact that, for instance, the different ways in which the 'Old Republic' is remembered by characters in the Star Wars universe depends very much on which faction they 
belong to, which narrative they accept. Narrative memory implies conscious or unconscious selectivity-forgetting-a process itself which is highly socially contingent. As such, we remember in accordance with the varied social frames and constraints which structure social reality, which shift and change not only in historical terms, but also over the course of a human life. In order to cope with the demands of culture, politics and society, memory practices are thus narrative practices (Brockmeier, 2000). Indeed, it is only this narrative aspect that allows us to think about ourselves historically, as individuals and as societies.

Accepting a certain narrative, then, changes the way in which we perceive our roles, and the world around us. We see this, for example, in Luke Skywalker's journey from a humble farmer to a Jedi Knight, and his discovery of new 'memories', which facilitates his change in perception. Where this becomes problematic-particularly in terms of the narratives of memory found in the original Star Wars saga-is in relation to the power relations and interests which are never questioned (those of the Rebel Alliance and the Jedi Knighthood) and which are concealed within these narratives of memory. Even if the power interests of the Galactic Empire are also problematic, it does not prevent us from questioning the agendas of the Republic. Indeed, doing so may awaken us to the necessity of questioning the agendas and power interests of our own societies, especially in their political expressions. For example, we may prefer living in a liberal democratic society to living in a dictatorship or a theocracy, but that does not justify everything said liberal democracy does in the name of freedom. This theme is only too well known to us, and the absence of unmanned drones in the arsenal of the Rebel Alliance might simply have been due to the fact that they might have seemed too much like science fiction at the time of production. Sadly, the same could not be thought today, which perhaps explains the appearance of combat drones only in the later films, Episodes I, II and III, in anticipation of those we find increasingly used in our own world to bomb from a 'safe' distance.

The social construction of narratives of memory is clearly a topic receiving increasing attention by scholars such as Assman and Brockmeier, who stress that narratives of the past should be understood in terms of the specific cultural context in which they are told; what we might call their ecosystem of the imaginaire. In the case of the Jedi, the universe of the original 
Star Wars saga, that galaxy 'far, far away'. Of course, there is no ideal scheme of remembering and forgetting; it should be clear that these are patterns that emerge in correspondence with cultural norms and discursive patterns of narration in society, and which are linked to patterns of power relations (Foucault, 1984; 1984a; Brockmeier, 2002). In terms of the importance which remembering and forgetting hold for examining Star Wars, and in particular the Jedi, I would refer to Assman, who understands collective forgetting as the disappearance of those aspects of the past which no longer hold meaningful relations to the present, the "structural amnesia" of society (1995, p.371). That they should be 'forgotten', though, does not mean that they are gone, nor that they are irrelevant. This is an insight that becomes instinctive if we consider the tendency of structures, forms and mythemes from the past to resurface in the imaginaires and narratives which populate our cultures and societies. This can be seen in the similarities between Star Wars and ancient epics, or the Jedi Knights and the Knights Templar. Above all, though, we see this in the structures of everyday life, where our modes of sociality take on an archaic structure, albeit in digital form. As Maffesoli (1995, p.170) has written, this "synergie de l'archaigue et du developpement technologique" ["synergy of the archaic with technological development"] can be increasingly seen in the decline of 'mass society', from the mass societies of modernity to fragmented contemporary groupings, a phenomenon facilitated by advancements in communications technology. This could partly explain the resurgence in popularity of epic narratives such as Star Wars. Where this becomes problematic, particularly in the case of Star Wars, is where these narratives of memory 'forget' or otherwise conceal key truths, binding characters to one or other form or morality, such as in the case of the deception by Obi-Wan Kenobi and Yoda with regard to the truth of Luke Skywalker's parentage.

In Episode V: The Empire Strikes Back (1980), Yoda at first deceives Luke Skywalker into following him home, and for some time conceals his true identity, despite knowing that he is the one Luke Skywalker is seeking. Later in this scene, Luke Skywalker asks of Yoda: "How am I to know the good side from the bad?"-a reasonable question, surely-to which Yoda can only reply: "You will know, when you are calm, at peace, passive. A Jedi uses the force for knowledge and defense-never for attack." This hardly seems like a sound epistemological basis for a system of ethics, never mind anything approaching 
the religious devotion which Yoda insists being a Jedi demands, a devotion based largely upon a loose belief in something known only as 'the Force'. Moreover, the line between attack and defense becomes increasingly blurred as the Star Wars saga progresses, particularly when Luke Skywalker stages his 'rescue mission' of Han Solo from Jabba the Hutt, murdering several nonaligned civilians in the process. Later, when Luke Skywalker asks "but tell me why I can't...," Yoda immediately interrupts him to say "No, no, there is no why. Nothing more will I teach you today. Clear your mind of questions" (1980).

All this discussion takes place before Yoda sends Luke Skywalker into the cave where he comes face to face with the 'Dark Side'. There, he meets a spectre of Darth Vader with whom he is forced to fight. Perhaps the most startling part of this deception is that Yoda encouraged him not to bring his weapons, yet when Luke has decapitated Darth Vader he sees that it truly was a deception and is confronted by a vision of having beheaded himself. It is at this point that the deep ambiguity in the myth of the Jedi is transposed; Skywalker is of course less troubled by the fact of the illusion than he is by what the illusion reveals-that there is but a fine and ultimately arbitrary line between the Jedi and the Dark Side, and he is pulled in each direction by the enormity of memory, myth, and deception that he is steeped in by this stage. Throughout the rest of his training on the planet Dagobah, such deception and manipulation continues in the name of indoctrination. When, later in Episode $V$ : The Empire Strikes Back, Luke Skywalker tries to leave Dagobah to help his friends, Han Solo and Princess Leia, Yoda actively encourages him to abandon them, telling Luke that if he went he would destroy all they had fought for, even going so far as to encourage him to "sacrifice" them. Even after Obi-Wan Kenobi appears to try and prevent Luke Skywalker from going to rescue them, Luke persists. The key to their opposition to the rescue mission is to be found in the fact that Darth Vader reveals to Luke Skywalker that he is his son, revealing their earlier deception, a fact that becomes clear when Luke Skywalker says to himself after the confrontation with Darth Vader, "Ben, [Obi-Wan Kenobi] you tricked me." In Episode VI: The Return of the Jedi, this deception comes all the more clearly into focus, when Luke Skywalker-despite being aware of the deception of Obi-Wan Kenobi and Yoda-returns to the planet Dagobah to finish his training as a Jedi knight, at which point, 
seemingly miraculously, Yoda, the nine hundred-year old Jedi master, 'chooses' to die. This act is a last resort on the part of Yoda and the ghost of Obi-Wan Kenobi to finish their indoctrination of young Luke Skywalker, to prevent him from becoming a critically minded individual, and to hold him to his imagined status of Jedi knight, which they have carefully convinced him of since the beginning. This process of indoctrination represents the weaving of a narrative of memory, based upon the imaginaire of the Jedi which is all the more potent in the world of the Star Wars saga for its romantic appeal. On his deathbed, Yoda convinces Luke Skywalker that he really is a Jedi, and incites him to revive recruitment into the order of Jedi Knights, and to kill his father, Darth Vader, of course-the last inconsistency in the narrative web that Obi Wan Kenobi and Yoda have so carefully weaved. Upon being forced to admit that Darth Vader is the father of Luke Skywalker, Yoda backtracks, bemoaning the fact that he won't able to finish his 'training' (indoctrination), a clear sign of his desperation.

After Yoda has died, or killed himself as an act of emotional manipulation, the ghost of Obi-Wan Kenobi appears to Luke Skywalker, starting the following emotive dialogue:

Luke Skywalker: You told me Vader betrayed and murdered my father.

Obi-Wan Kenobi: Your father was seduced by the dark side of the force. He ceased to be Anakin Skywalker and became Darth Vader. When that happened, the good man who was your father was destroyed. So what I told you was true, from a certain point of view.

Luke Skywalker: A certain point of view.

Obi-Wan Kenobi: Luke, you're going to find that many of the truths we cling to depend greatly on our own point of view. Anakin was a good friend.

This brief lesson in subjectivity and relativism is perhaps intended to distract from the main point: that Obi-Wan Kenobi lied outright to Luke Skywalker. Here, again, we see this same ambiguity, the arbitrary fluidity that exists even between the forces that seem most opposed in the narrative, the Jedi and the Dark Side. Like the experience in the cave in Episode $V$, and the final scene of Episode VI where Darth Vader is reconciled with the spirits of Yoda and ObiWan Kenobi, this dialogue demonstrates to us the deep ambiguity between the Jedi and the Dark Side, between the concepts of 'good' and 'evil' presented in the narrative. 
Perhaps the most tragic instance of deception in the film is when Luke Skywalker participates in fooling the indigenous Ewok people of the planet Endor that the droid $\mathrm{C}_{3} \mathrm{PO}$ is in fact a god. They then use this deception to press the neutral Ewok people into participating in their war with the Empire, a fight in which they suffer many casualties due to their technological inferiority and tiny size. Finally, though, Luke Skywalker, after having fully assumed his mantle as Jedi and the narratives of memory that go with it, inspires enough pity in his father to cause him to kill his friend and ally, The Emperor, an apparently redemptive act on the part of Darth Vader. More than simply a killing, though, this death certainly would have had the effect of throwing the entire galaxy into chaos as the Rebel Alliance scramble for control. The redemptive moment of Vader's death sees the supremacy of the narrative of memory surrounding the imaginaire of the Jedi, whereby even his hitherto foe, Darth Vader, recognizes it, and aids Skywalker and the Rebel Alliance in overthrowing the established order. Vader himself is later rehabilitated, joining Obi-wan Kenobi and Yoda in disembodied form, simultaneously solidifying the Jedi/Rebel Alliance narrative of memory and power, and signaling to us the ambiguous relation between the Jedi and the Dark Side.

I have begun to explore in this essay the problematic nature of the order of Jedi Knights as represented in the original Star Wars saga. This brief analysis has only scratched the surface in helping us to understand the dangers of narratives of memory that are used to indoctrinate characters such as Luke Skywalker, convincing them that they are justified in their arbitrary and extrajuridical violence. As we have seen, the many instances of violence and deception that Luke Skywalker participates in are as a direct result of his belief that he is a Jedi. This belief is one that he gained not only because of the intricate web of lies and half-truths fed to him by Obi-Wan Kenobi and the character known as Yoda, but owing to the social imaginaires which existed in the world of the Star Wars saga, lending a potency and credibility to Luke's claims that his belief was all the more powerful because of its intangibility. It is precisely claims, doctrines and systems of belief such as these which make the Star Wars saga a good 'mirror' for our own world, one in which we can perhaps more clearly discern the patterns of deception and the currents of power relations present in the narratives of memory and the imaginaires which 
abound in our societies. In that sense, the overly simplistic scheme of 'good vs. evil' morality fortified by the imaginaire of the Jedi and the accompanying narratives of memory that we find in the original Star Wars saga is very much of its time, in that it reflects the mainstream political narratives of western culture in the late seventies, at the height of the Cold War. These juxtapositions of morality, as we have seen, though perhaps all the more complex, are just as present in the contemporary world.

\section{Notes}

1. Quotations given in French have been taken from French sources which have not been translated to English; the translations given are the author's own. References to the characters 'Yoda' and 'the Emperor' are first presented in quotation marks, since they are the only main characters who are presented with only a first name, or in the case of the Emperor, a title. This is probably intended to add to their mystique, though I find it merely renders them more suspect. 


\section{Bibliography}

Assmann, J., 1995. Ancient Egyptian anti-Judaism: A case of distorted memory. In: D.L. Schacter, et al. eds., Memory distortion: How minds, brains and societies reconstruct the past. Cambridge, MA: Harvard University Press, pp. 365-376

St. Augustine, 1998. Confessions. Translated by H. Chandwick. Oxford: Oxford University Press

Brockmeier, J., 2000. Autobiographical time. Narrative Inquiry, 10(1), pp.51-73

Brockmeier, J., 2002. Remembering and forgetting: narrative as cultural memory. Culture \& Psychology, 8(1), pp.15-43

Borges, J. L., 2007. A new refutation of time. Labyrinths: selected stories \& other writings. New York: New Directions Books

Durand, G., 1993. Les structures anthropologiques de l'imaginaire. Paris: Dunod 1994. L’imaginaire. Essai sur les sciences et la philosophie de l'image, Paris: Hatier

Foucault, M., 1980. Power/knowledge: selected interviews and other writings. 1972-1977. Colin Gordon eds., translated by Colin Gordon, Leo Marshall, John Meplam and Kate Soper, Brighton: Harvester press 1982. The subject and power. In: Herbert Dreyfus, \& Paul Rabinow eds., translated by Paul Rabinow, Michel Foucault: beyond structuralism and hermeneutics. Chicago: University of Chicago Press, pp.208-229

1984. Truth and power. an interview conducted by Alessandro Fontana and Pasquale Pasquino, translated by Paul Rabinow. In: Paul Rabinow ed. The Foucault reader: an introduction to Foucault's Thought. London: Penguin, pp.308-319

1984a. On Power. In L'espress. July 6-12, 1984, pp.56-68. Translated by Alan Sheridan. Reprinted in Kritzman, Lawrence (ed.), 1988, Michel Foucault: politics, philosophy and culture: interviews and other writings 1977-1984. New York: Routledge, pp. 96-110 
1997, The birth of biopolitics. In: Rabinow, Paul ed. Michel Foucault, The essential works, 1954-1984, vol.1, ethics, subjectivity and truth. New York: The New Press, pp. 73-81

Halbwachs, M., 1950, La mémoire collective, Paris: Presses Universitaires de France

MacDubhghaill, R., 2012. Ars memoriae: la memoire collective et la sociologie del'imaginaire. In: CEAQ Sorbonne Paris V, Les Journées du CeaQ SocialitéPostmoderne XI, 21-22 June 2012. Paris: Paris V 2013. Mémoire culturelle, Sociétés, à venir.

MacIntyre, A., 2007. After virtue: a study in moral theory, Indiana: University of Notre Dame Press

Maffesoli, M., 1985. La connaissance ordinaire. Paris: Librarie des Méridiens 1995. Le temps revient. Paris: Desclée de brouwer 2006. Du nomadisme. Paris: La Table Ronde 2012. Nuit blanche. In Fondation d'enterprise Ricard, Invitations de l’imaginaire. Paris, France, 6 October 2012, Paris: Ricard

Muttitt, G. 2011. Fuel on the fire. London: Bodley head

Nietzsche, F. 2002. Jenseits von Gut und Böse. Zur genealogie der moral. Giorgio Colli and Mazzino Montinari, eds. Munich: Deutscher Taschenbuch Verlag

United States of Paris, Présidentielle 2012 Street Art Paris, 2012. Vote Darksidephenomenon. [Online] available at: http://blogs.paris.fr/unitedstatesofparis/2012/04/22/presidentielle-2012street-art-paris-vote-darkside-sticker-by-es [accessed 4 February 2013]

Quian Quiroga, R., 2011. Borges y la memoria. Buenos Aires: Sudamericana Simons, J., 2006. Foucault and the political, London: Routledge Star wars, Episode IV: a new hope, 1977. [Film] Directed by George Lucas. USA: Lucasfilm. Episode V: the Empire strikes back, 1980. [Film] Directed by George Lucas. USA: Lucasfilm 
Excursions 4:1

Episode VI: The return of the Jedi, 1983. [Film] Directed by George Lucas. USA: Lucasfilm

The pervert's guide to cinema, 2006. [Film] Directed by Sophie Fiennes/written by Slavoj Žižek. UK: P Guide Ltd

Wikipedia article, 2012. Jedi census phenomenon. [online] Available at:

<http://en.wikipedia.org/wiki/Jedi_census_phenomenon> [accessed 4 February 2013] 